\title{
Application of Asian pumpkin (Cucurbita ficifolia) serine proteinase for production of biologically active peptides from casein
}

\author{
Anna Dąbrowska ${ }^{\bowtie}$, Marek Szołtysik, Konrad Babij, Marta Pokora, Aleksandra Zambrowicz \\ and Józefa Chrzanowska
}

Department of Animal Products Technology and Quality Management, Wrocław University of Environmental and Life Sciences, Wrocław, Poland

\begin{abstract}
The main objective of this study was to determine potential application of a serine proteinase derived from Asian pumpkin for obtaining biologically active peptides from casein. The course of casein hydrolysis by three doses of the enzyme $(50,150,300 \mathrm{U} / \mathrm{mg}$ of protein) was monitored for 24 hours by the determinations of: hydrolysis degree $\mathrm{DH}(\%)$, free amino group content ( $\mu$ mole Gly/g), RP HPLC peptide profiles and by polyacrylamide gel electrophoresis. In all hydrolyzates analyzed antioxidant activities were determined using three tests: the ability to reduce iron ions in FRAP test, the ability to scavenge free radicals in DPPH test, and $\mathrm{Fe}^{2+}$ chelating activity. The antimicrobial activity of obtained peptide fractions was determined as the ability to inhibit the growth of Escherichia coli, Bacillus cereus and Pseudomonas fluorescens in a diffusion plate test. The deepest degradation, expressed as the $\mathrm{DH}[\%]$ and the free amino group content ( $67 \%$ and $7528 \mu$ mole Gly/ $\mathrm{mg}$, respectively), was noted in samples hydrolyzed with $300 \mathrm{U} / \mathrm{ml}$ of enzyme for 24 hours, while in other samples the determined values were about three and two times lower. The results were in agreement with the peptide profiles obtained by RP HPLC. The highest antioxidative activities determined in all tests were seen for the casein hydrolysate obtained with $300 \mathrm{U} / \mathrm{mg}$ protein of serine proteinase after $24 \mathrm{~h}$ of reaction (2.15 $\mu \mathrm{M}$ Trolox/ $\left.\mathrm{mg}, 96.15 \mu \mathrm{g} \mathrm{Fe}{ }^{3+} / \mathrm{mg}, 814.97 \mu \mathrm{g} \mathrm{Fe}{ }^{2+} / \mathrm{mg}\right)$. Antimicrobial activity was presented in three preparations. In other samples no antimicrobial activity was detected.
\end{abstract}

Key words: Asian pumpkin, bioactive peptides, casein

Received: 10 December, 2012; revised: 21 February, 2013; accepted: 14 March, 2013; available on-line: 21 March, 2013

\section{INTRODUCTION}

Food-protein hydrolysates are commonly used as supplements for individuals requiring specific protein diet. They are a valuable source of peptides with diverse biological activities. The type of activity manifested after hydrolysis is determined not only by the precursor protein(s) and their primary structure, but also by the nature of the enzyme used for the hydrolysis.

Numerous dietary proteins can be a source of biologically active peptides. These peptides, inactive within the sequence of the native protein, can be released both during digestion in the gastrointestinal tract and during food processing (Korhonen et al., 1998; Korhonen \& Pihlanto-Leppälä, 2001). The bioactive peptides usually contain from 3 to 20 amino acid residues. Their effect on the body most frequently relates to the nervous, immune, cardiovascular and digestive systems (Haque \& Chand, 2008).

Commercial food products containing bioactive peptides, available on the market in many countries, are often obtained from milk proteins - casein and whey proteins. Their hydrolysis is usually carried out using commercially available proteolytic enzymes of animal (digestive enzymes: pepsin, trypsin and chymotrypsin), plant (papain, ficin, bromelain) or microbial origin.

One of the most important, though rarely detected, activity of biologically active peptides, is their antimicrobial activity. Peptides with antibacterial properties are considered to be an important component of the innate immune response, acting as the "first line of defense", especially in tissues and organs such as lung mucosa or the small intestine, which are often exposed pathogens. In recent years, particular attention has been paid to the antibacterial peptides derived from natural sources.

As shown by Haque and Chand (2008), casein may be an important source of peptides with antimicrobial properties. Peptides with this activity have been identified in hydrolysates of different fractions of casein (Lahov et al., 1971; Haque \& Chand, 2008) and exhibit an antibioticlike activity against a wide variety of microbes (Staphylococcus spp., Sarcina spp., Lactobacillus spp., Bacillus subtilis, Diplococcus pneumoniae, Streptococcus pyogenes, Candida albicans, Streptococcus pyogenes and Listeria monocytogenes). Peptides released during casein degradation with different digestive enzymes demonstrated also in vivo an antibiotic-like activity while in vitro they inhibited the growth of bacteria from the Lactobacillus group and other Gram-positive bacteria. The peptide given to dairy cattle with diagnosed mastitis exhibited antibiotic-like effects (Haque \& Chand, 2008).

The oxidative processes in the human body and in food products are a the subject of intensive research. Oxidation reactions in living organisms play an important role in old age diseases such as Alzheimer's disease, rheumatoid arthritis and atherosclerosis (Pihlanto, 2006). In food products, oxidative processes associated with oxidation of lipids cause deterioration of quality - rancid smell, unacceptable taste and shorter shelf-life.

Diverse peptides and protein hydrolysates can reduce the rate of lipid auto-oxidation. They also act as heavy

e-mail: anna.dabrowska@up.wroc.pl

Abbreviations: $\mathrm{DH}$, hydrolysis degree; FAG, free amino group; TCA trichloric acid; DPPH, 2,2-di(4-tert-octylphenyl)-1-picrylhydrazyl; FRAP, ferric reducing antioxidant power; RP HPLC, reversed-phase high performance liquid chromatography; TFA, trifluoroacetic acid; TSB, tryptic soy broth; TPTZ, 2,3,5-triphenyltetrazolium chloride 
metal chelators and free radical scavengers. The antioxidative activity of peptides released from different proteins is due to the presence in their sequence of amino acid residues, such as histidine or tyrosine, known for their antioxidant properties. Similar properties are also shown by methionine, lysine and tryptophan.

Recent studies have shown that hydrolysis of casein using digestive enzymes or by the action of proteolytic enzymes of lactic acid bacteria can produce antioxidative peptides (Korhonen \& Pihlanto, 2006). A high ability to inhibit the oxidation of linolenic acid was observed for a fraction containing fragments f169-176 and f33-48 of beta-casein (Pihlanto, 2006).

The aim of this study was to obtain biologically active peptides from casein degraded with a non-commercial proteolytic enzyme obtained from Asian pumpkin.

\section{MATERIALS AND METHODS}

Isolation of the enzyme. Serine proteinase was isolated from Asian pumpkin by the method of Dryjański et al. (1990).

Determination of enzyme activity. Proteolytic activity of serine proteinase was determined with the use of $2 \%$ casein solutions in $0.1 \mathrm{M}$ Tris/ $\mathrm{HCl}$ at $\mathrm{pH}$ 8.6. The substrate was incubated with the enzyme for 10 minutes at $35.5^{\circ} \mathrm{C}$. After this time the reaction was stopped by the addition of $5 \%$ trichloroacetic acid (TCA). The sample was then centrifuged $10 \mathrm{~min}$. for $5500 \times g$ and absorbance measured at $\lambda=280 \mathrm{~nm}$. One unit of enzyme activity was defined as the amount of enzyme giving an increase in absorbance of 0.1 under specified conditions.

Substrate. Isoelectric casein was isolated from microfiltered and defatted milk, which was heated to $28^{\circ} \mathrm{C}$ and acidified with $1 \mathrm{M} \mathrm{HCl}$ at $\mathrm{pH}$ 4.6. Precipited casein was washed several times with distilled water and lyophilized.

Determination of protein content. Protein content was determined by colorimetric method of Lowry et al. (1951).

Hydrolysis of casein. Enzymatic hydrolysis assays of $1 \%$ casein solution were carried out in $0.1 \mathrm{M}$ Tris/ $\mathrm{HCl}$ buffer at $\mathrm{pH} 8.0$ at $37^{\circ} \mathrm{C}$ for $0 ; 0.5 ; 1 ; 3 ; 5$; and 24 hours using serine proteinase from Asian pumpkin at doses of 50,150 or $300 \mathrm{U} / \mathrm{mg}$ of protein The hydrolysis was terminated after $24 \mathrm{~h}$ by thermal inactivation (for biological activity determinations) or by the addition of $10 \%$ trichloric acid (TCA) $(1: 1 \mathrm{v} / \mathrm{v})$.

The degree of hydrolysis. The course of the hydrolysis was monitored by the determination of the hydrolysis degree according to Spellman (2003).

The free amine group content was evaluated with the method described by Kuchro et al. (1983)

Reversed-phase high performance liquid chromatography (RP-HPLC). Peptide profiles of casein hydrolysates were determined by RP-HPLC. Separation was performed using a Zorbax XDB- $\mathrm{C}_{18}$ Agilent column $(250 \times 4.5 \mathrm{~mm})$ equilibrated with $0.1 \%$ TFA (trifluoroacetic acid) (phase A). The casein hydrolysate samples of $500 \mu \mathrm{l}$ were precipitated as above and solubilized in 0.1 $\mathrm{M}$ Tris $/ \mathrm{HCl}$ buffer, $\mathrm{pH} 7.6$ with $6 \mathrm{M}$ urea and $0.24 \%$ 2 -mercaptoethanol and loaded on the column. Separation was performed at a flow rate of $1 \mathrm{ml} / \mathrm{min}$ at $30^{\circ} \mathrm{C}$. The absorbed peptides were eluted with a gradient $(0$ $100 \%)$ of phase B $(0.1 \%$ TFA in acetonitrile). Absorbance was read at $230 \mathrm{~nm}$ (Ardo \& Gripon, 1995).

Electrophoretic separation of peptides was performed according to Shaggar and von Jagow (1987). The gels were stained in $0.1 \mathrm{M} \mathrm{NaOH} / \mathrm{NH}_{4} \mathrm{OH}$ with the addition of $\mathrm{AgNO}_{3}$ in final concentration of $0.2 \%$.

Determination of antimicrobial activity was performed by diffusion test according to Pasupuleti et al (2009). One-hundred microliters of $1 \times 10^{6}$ bacterial cell suspension was plated on TSB agar plates. Sterile blotting-paper discs soaked with appropriate peptide solution $(100 \mu \mathrm{g}$ per circle) were placed on the surface of the plates and incubated at $37^{\circ} \mathrm{C}$ for $24 \mathrm{~h}$. Then, bacterial growth inhibition zones around the blottingpaper discs were measured. A zone exceeding $2 \mathrm{~mm}$ was accepted as growth inhibition.

Determination of antioxidant activity as the ability to scavenge DPPH free radicals. Antioxidant activity was determined by a modified method of Yen and Chen (1995) as the ability to bind DPPH (2,2-di(4-tertoctylphenyl)-1-picrylhydrazyl) free radicals in an aqueous solution of peptides during 30 minutes of incubation. After this time, absorbance measurements were made at $517 \mathrm{~nm}$. The antioxidant activity of a $1-\mathrm{mg} / \mathrm{ml}$ peptide solution was determined on the basis of a standard curve prepared for Trolox.

Determination of antioxidant activity using the FRAP method (Benzie \& Strain, 1996). Antioxidant activity was determined as the ability of the hydrolysate to reduce the $\mathrm{Fe}$ (III) to $\mathrm{Fe}$ (II) ions in reaction with TPTZ (2,3,5-triphenyltetrazolium chloride). Absorbance measurement was made at $593 \mathrm{~nm}$. The concentration of $\mathrm{Fe}^{2+}$ ions in $1 \mathrm{mg} / \mathrm{ml}$ the protein solution was determined on the basis of the standard curve for an $\mathrm{FeSO}_{4}$ solution.

Determination of iron Fe (II) ion chelation (Xu et al., 2007). Chelation of iron ions was determined by colometric measurement of $\mathrm{Fe}$ (II) not bound by hydrolysate in a reaction mixture using ferrozine (3-(2-pyridyl)-5,6-diphenyl-1,2,4-triazine-p,p'-disulfonic acid monosodium salt hydrate). Absorbance measurement was done at $562 \mathrm{~nm}$. The ability to chelate iron
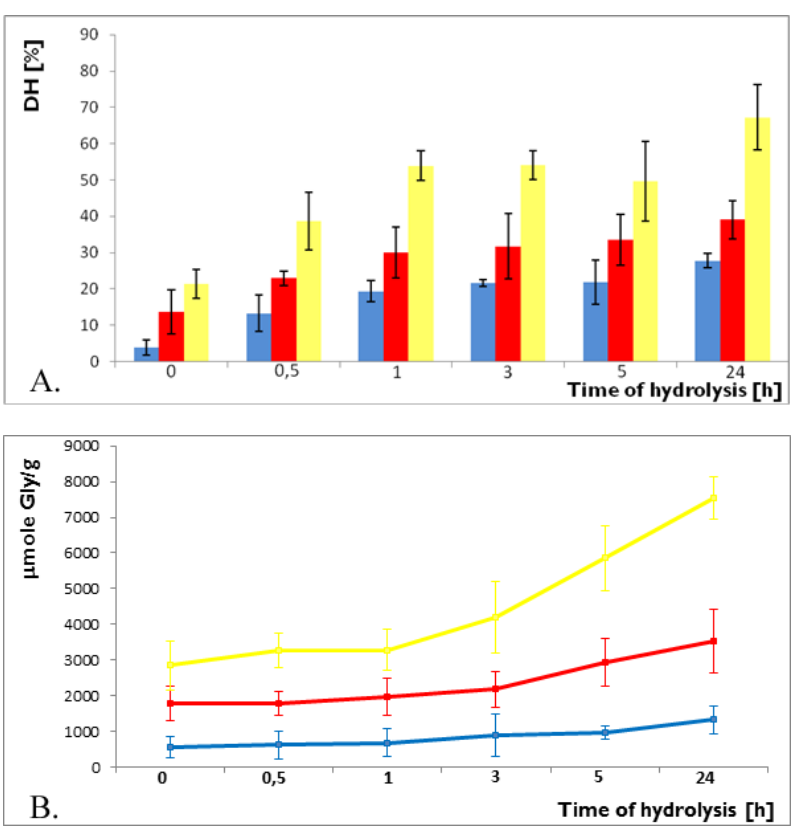

Figure 1. Casein hydrolysis course by different doses $f(\square 50 \mathrm{U} /$ $\mathrm{mg} ; \quad 150 \mathrm{U} / \mathrm{mg} ; \quad 300 \mathrm{U} / \mathrm{mg}$ ) of serine proteinase isolated from Asian pumpkin (Cucurbita ficifolia) expressed as (A) the DH (\%) and (B)

Free amino group content ( $\mu$ mole $\mathrm{Gly} / \mathrm{g}$ ). 
ions was determined on the basis of a standard curve for an $\mathrm{FeCl}_{2}$ solution.

\section{RESULTS}

The course of the enzymatic hydrolysis of casein with the use of serine proteinase isolated from Asian pumpkin (Cucurbita ficifolia) was monitored by determination of hydrolysis degree expressed as precentage (DH). The obtained results are presented in Fig. 1A, B. The highest DH was observed after 24 hours of hydrolysis in all hydrolysates analyzed. The highest value of DH (67.20\%), was observed for the 24-hour hydrolysates obtained with the enzyme dose of $300 \mathrm{U} / \mathrm{mg}$ per substrate protein, the lowest $(27.77 \%)$ for the hydrolysate obtained with the dose of $50 \mathrm{U} / \mathrm{mg}$.

During the course of protein degradation in all hydrolysates also a proportional increase of the free amino group content (FAG) was observed (Fig. 1B.). The highest amount was observed in hydrolysates obtained with $300 \mathrm{U} / \mathrm{mg}$ of enzyme, which after the 24 hours of hydrolysis reached the value of $7528 \mu$ mole Gly/g. For other variants, the obtained values after the same time of hydrolysis were five times and two times lower: 1326.8 $\mu \mathrm{mole}$ Gly/g for $50 \mathrm{U} / \mathrm{mg}$ and $3515.9 \mu \mathrm{mole}$ Gly/g for $150 \mathrm{U} / \mathrm{mg}$. In all hydrolysates tested at time " 0 " the levels of DH and free amino group content were $3.84 \%$, $13 \%, 21 \%, 31 \%$ and 568, 1787 and $2854 \mu$ mole Gly/g respectively, which can be explained by the high susceptibility of casein to degradation by the enzyme used in the test. A similar observation was made by Curotto et al. (1989) for other proteins degraded with the proteinase from Asian pumpkin. The enzyme was highly reactive against the proteins investigated and preserved its activity in a wide range of $\mathrm{pH}$.

The hydrolysis degree and free amino groups content were well correlated with the RP HPLC profiles (Fig. 2, A-C) and electrophoretic separation of peptide fractions (Fig 3). In all chromatographic analyses of hydrolysates after 24 hours of reaction the presence of a low molecular mass fractions were noted, which were released from the column at low concentrations of acetonitrile. The highest concentration of those fractions was detected in samples with the highest hydrolysis degree. The deepest degradation of casein fractions was observed in hydrolysates obtained with enzyme doses of 150 and $300 \mathrm{U} / \mathrm{mg}$ after $24 \mathrm{~h}$ of hydrolysis.

The proteolysis was also monitored by electrophoretic separation of peptide fractions obtained with three doses of serine proteinase $(50 \mathrm{U} / \mathrm{mg}, 150 \mathrm{U} / \mathrm{mg}$ and $300 \mathrm{U} / \mathrm{mg}$ ) after 5 and 24 hours of hydrolysis. In all samples the gradual disappearance of casein fractions was observed and the appearance of fractions with lower molecular masses. In fractions obtained with enzyme doses of 50 and $150 \mathrm{U} / \mathrm{mg}$ after $24 \mathrm{~h}$ of reaction the presence of peptides with molecular masses below $5 \mathrm{kDa}$ is observed, while on lanes with fractions obtained with the dose of $300 \mathrm{U} / \mathrm{mg}$, those peptides were absent.

The antioxidant activities were analyzed using three tests: FRAP, DPPH, and $\mathrm{Fe}^{2+}$ chelating activity. All preparations analyzed showed the ability to scavenge free radicals in the DPPH test, which was correlated with the time of hydrolysis (Table 1). The highest activities were detected in samples obtained with the lowest and the highest enzyme dose (50 and $300 \mathrm{U} / \mathrm{mg}$ ), while in samples obtained with $150 \mathrm{U} / \mathrm{mg}$ the activity was about five times lower in all analyzed reaction times.

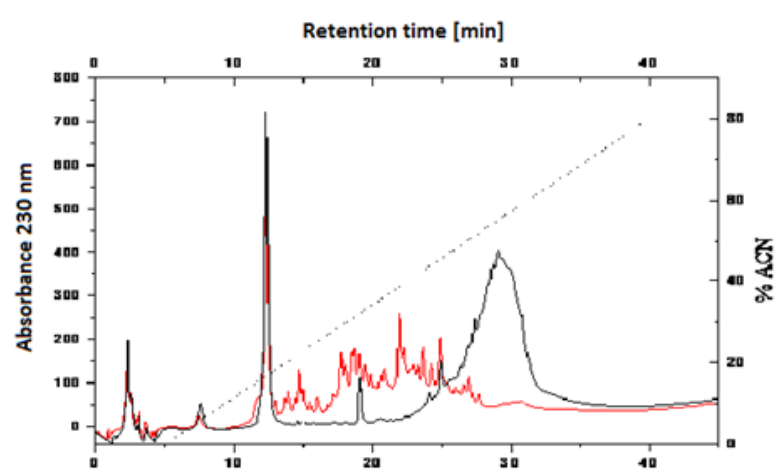

A.

Retention time [min]

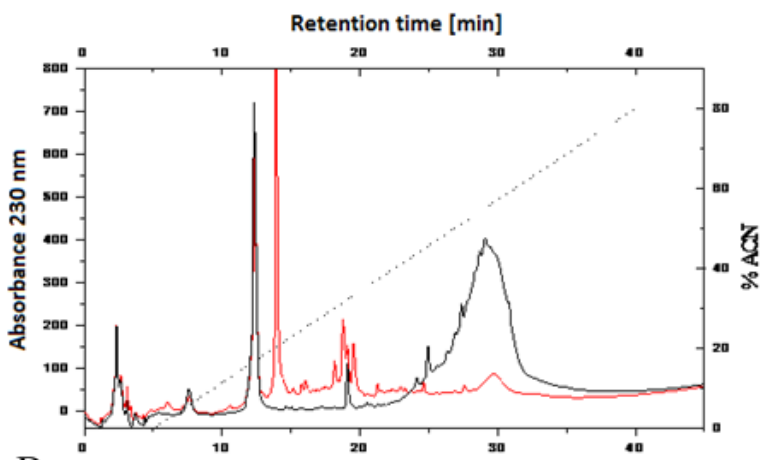

B.

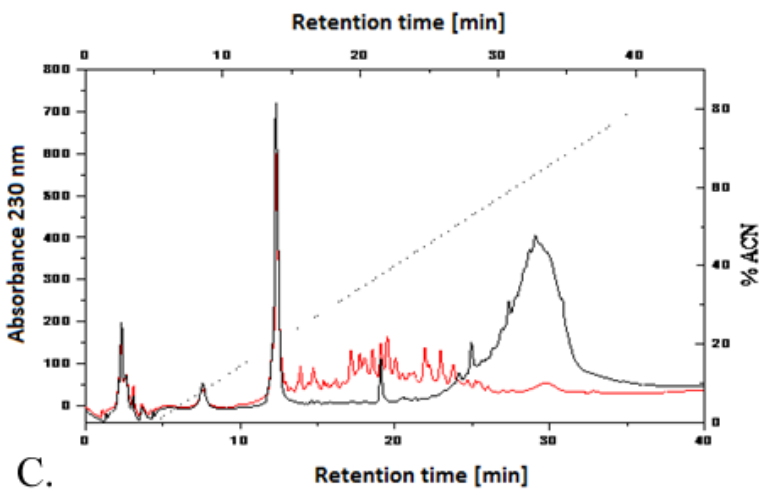

Figure 2. RP-HPLC profiles of peptide fractions obtained after 24 hours of casein hydrolysis with different doses of serine proteinase isolated from Asian pumpkin (Cucurbita ficifolia) Proteinase of: (A) $50 \mathrm{U} / \mathrm{mg}$; (B) $150 \mathrm{U} / \mathrm{mg}$, (C) $300 \mathrm{U} / \mathrm{mg}$, (red).

Undigested $1 \%$ isoelecrtoc casein was used as control of hydrolysis (black).

The peptides obtained after enzymatic hydrolysis of casein showed the ability to reduce iron ions in the FRAP test in all analyzed variants. The highest activity, $96.15 \mu \mathrm{g} \mathrm{Fe} \mathrm{F}^{3+} / \mathrm{mg}$, was detected in the hydrolysate obtained with the enzyme dose of $300 \mathrm{U} / \mathrm{mg}$ after $24 \mathrm{~h}$ of reaction, while in the other samples it was about 3 to 4 times lower. In samples obtained with lower doses of the enzyme, the $\mathrm{Fe}^{3+}$ reducing activities were increasing gradually with the time of the reaction to the maximal value of $30.29 \mu \mathrm{g} \mathrm{Fe} \mathrm{Fe}^{3+} / \mathrm{mg}$.

Also the $\mathrm{Fe}^{2+}$ chelating activities were detected in all samples. The analyzed hydrolyzates showed the chelating activity also at the beginning of the reaction at the level of 348.80 to $510.36 \mu \mathrm{g} \mathrm{Fe} \mathrm{Fe}^{2+} / \mathrm{mg}$, which can be explained by the ability of non-hydrolysed casein to complex $\mathrm{Fe}^{2+}$ ions (Cervato et al.,1999; Hekmat \& McMahan, 1998). The increase of this activity in hydrolysates 


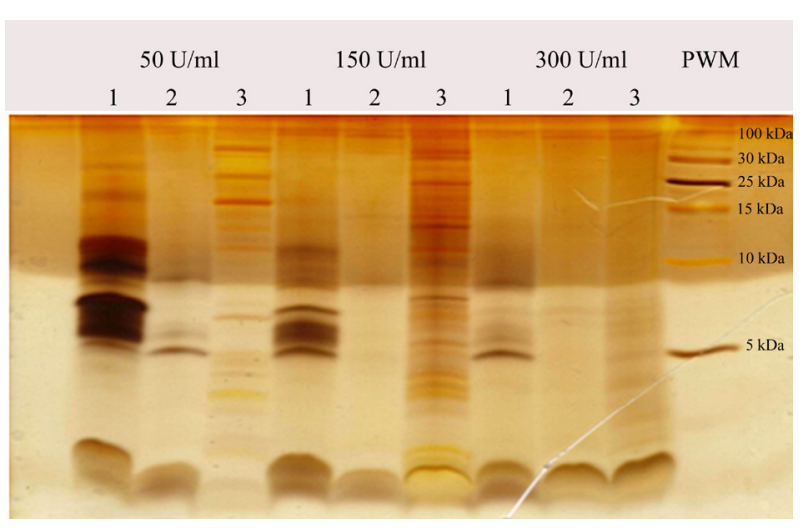

Figure 3. Electrophoretic separation of peptide fractions obtained after casein hydrolysis by different doses $(50 \mathrm{U} / \mathrm{ml} ; 150$ $\mathrm{U} / \mathrm{ml} ; 300 \mathrm{U} / \mathrm{ml}$ ) of serine proteinase isolated from Asian pumpkin (Cucurbita ficifolia) after 1, $0 \mathrm{~h} ; 2,5 \mathrm{~h}$ and 3, $24 \mathrm{~h}$ of reaction. PWM, Protein Weight Marker.

obtained with proteinase doses of 50 and $150 \mathrm{U} / \mathrm{mg}$ after $24 \mathrm{~h}$ of reaction was approximately $50 \%$ of the initial level. The highest chelating activity (815 $\mu \mathrm{g} \mathrm{Fe}^{2+} /$ $\mathrm{mg}$ ) was determined in hydrolysates obtained after $24 \mathrm{~h}$ of hydrolysis with the highest dose of the enzyme.

The antimicrobial activity of the obtained peptide fractions was determined as the ability to inhibit the growth of Escherichia coli, Bacillus cereus, Pseudomonas fluorescens in a diffusion plate test (Table 2). The bacteria were plated and cultured for $24 \mathrm{~h}$ at $37^{\circ} \mathrm{C}$ with blotting-paper discs soaked in the peptide solution $(100 \mu \mathrm{g})$ and placed on the plate. Then the reduction of their growth was determined as inhibition zones. The activities were analyzed in fraction after $5 \mathrm{~h}$ and $24 \mathrm{~h}$ of hydrolysis with three doses of the enzyme. Growth inhibition was observed on plates with $B$. cereus for casein hydrolysates degraded for $24 \mathrm{~h}$ with 150 and $300 \mathrm{U} / \mathrm{mg}$ of enzyme, and for $P$. fluorescens for samples with the highest dose of the enzyme only, but for both analyzed times: 5 and $24 \mathrm{~h}$.

\section{DISCUSSION}

The course of casein hydrolysis by three doses of the serine proteinase from Asian pumpkin was monitored for 24 hours by determinations of: hydrolysis degree $\mathrm{DH}$ $[\%]$, free amino group content ( $\mu$ mole Gly/g), RP HPLC peptide profiles, and polyacrylamide gel electrophoresis.

The casein degradation, observed already at the very begining of the hydrolysis process, was positively correlated with the time of hydrolysis and the enzyme dose.
Under the test conditions the deepest degradation, expressed as the $\mathrm{DH} \%$ and the free amino group content (67\% and $7528 \mu$ mole Gly/mg respectively), was noted in samples hydrolyzed with $300 \mathrm{U} / \mathrm{mg}$ of enzyme for 24 hours, while in other samples the determined values were about three and two times lower. The presence of casein degradation products at time zero suggests high susceptibility of casein to proteolytic degradation starting just after addition the enzyme to the reaction mixture. Similar remarks were made by Czajgucka et al. (2007) and Bruno et al. (2010) who determine a high increase in water soluble nitrogen fraction in the first minutes of reaction during the casein degradation by microbial and plant proteinases.

Despite the high proteolytic activity of the enzyme, in all 24-hours casein hydrolysates the DH did not exceed $70 \%$. This fact can be explained by a lower number of peptide bonds accessible for the enzyme at that stage of the reaction, (Netto \& Galeazzi, 1998) or by the inhibition of the reaction by hydrolysis products.

The determined $\mathrm{DH} \%$ and $\mathrm{FAG}$ results were in agreement with the peptide profiles obtained by RP HPLC. Low-molecular-mass fractions eluted from the column at low concentration of acetonitrile were seen on all obtained chromatograms of hydrolyzed samples. They were more abundant in samples with high $\mathrm{DH} \%$. The substrate peaks were absent in the peptide profiles obtained with 150 or $300 \mathrm{U} / \mathrm{mg}$ of the proteinase.

Recent studies shows that casein hydrolysates obtained with different proteolytic enzymes may contain peptides with different biological activies (Korhonen \& Pihlanto, 2006; Meisel, 2004; Suetsuna et al., 2000). It was shown that fragments $\mathrm{f169-176}$ and $\mathrm{f33}-48$ of beta-casein inhibit the oxidation of linolenic acid by (Pihlanto, 2006). The antioxidative properties of casein hydrolysates are caused by the presence of amino acid residues, such as histidine or tyrosine, known for their antioxidant properties. Similar properties are also shown by methionine, lysine and tryptophan. The amino acid composition, the sequence and conformation of peptides also have an impact on their antioxidant properties. The presence of proline residues increases the activity of the peptides and hydrophobic groups contribute to their interaction with linolenic acid (Flaczyk et al., 2005; Iwaniak \& Minkiewicz, 2007; Park et al., 2001; Rival et al., 2001; Suetsuna et al., 2000).

The antioxidant activities of analyzed hydrolyzates were analyzed using three tests: FRAP, DPPH and $\mathrm{Fe}^{2+}$ chelating activity (Table 1).

The DPPH analysis showed that casein hydrolysates obtained with enzyme doses of 50 and $300 \mathrm{U} / \mathrm{mg}$ had similar antioxidant activity. A lower activity $(0.44 \mu \mathrm{M}$

Table. 1. The antioxidant activities of peptide fractions obtained after casein hydrolysis by serine proteinase isolated from Asian pumpkin (Cucurbita ficifolia).

\begin{tabular}{|c|c|c|c|c|c|c|c|c|c|}
\hline \multirow{3}{*}{ Hydrolysis time (h) } & \multicolumn{3}{|c|}{ DPPH [ $\mu \mathrm{M}$ Trolox/mg] } & \multicolumn{3}{|c|}{$\operatorname{FRAP}\left(\mu \mathrm{g} \mathrm{Fe}{ }^{3+} / \mathrm{mg}\right)$} & \multicolumn{3}{|c|}{ Chelating $\mathrm{Fe}^{2+}\left(\mu \mathrm{g} \mathrm{Fe}{ }^{2+} / \mathrm{mg}\right)$} \\
\hline & \multicolumn{9}{|c|}{ Enzyme dose $(\mathrm{U} / \mathrm{ml})$} \\
\hline & 50 & 150 & 300 & 50 & 150 & 300 & 50 & 150 & 300 \\
\hline 0 & 0.68 & 0.06 & 0.77 & 11,56 & 19.32 & 24.58 & 348.80 & 429.71 & 510.36 \\
\hline 0.5 & 0.63 & 0.18 & 1.08 & 9.24 & 23.26 & 37.22 & 385.21 & 474.81 & 730.35 \\
\hline 1 & 0.73 & 0.29 & 1.20 & 11.07 & 25.83 & 33.61 & 367.55 & 483.68 & 787.17 \\
\hline 3 & 1.16 & 0.21 & 1.25 & 9.26 & 27.00 & 36.02 & 429.59 & 609.82 & 795.82 \\
\hline 5 & 1.09 & 0.41 & 1.54 & 11.14 & 29.73 & 36.35 & 448.07 & 722.82 & 819.87 \\
\hline 24 & 2.21 & 0.44 & 2.15 & 28.04 & 30.29 & 96.15 & 571.97 & 782.93 & 814.97 \\
\hline
\end{tabular}


Table. 2. The antimicrobial activity of peptide fractions obtained by proteolytic degradation of casein with the use of serine proteinase isolated form Asian pumpkin.

\begin{tabular}{|c|c|c|c|c|c|c|}
\hline \multirow{3}{*}{$\begin{array}{l}\text { Bacterial species } \\
\text { Time of hydrolysis }\end{array}$} & \multicolumn{6}{|c|}{ Enzyme dose [U/mg] } \\
\hline & \multicolumn{2}{|c|}{50} & \multicolumn{2}{|c|}{150} & \multicolumn{2}{|c|}{300} \\
\hline & $5 \mathrm{~h}$ & $24 \mathrm{~h}$ & $5 \mathrm{~h}$ & $24 \mathrm{~h}$ & $5 \mathrm{~h}$ & $24 \mathrm{~h}$ \\
\hline Escherichia coli & - & - & - & - & - & - \\
\hline Bacillus cereus & - & - & - & + & + & + \\
\hline Pseudomonas fluorescens & - & - & - & - & + & + \\
\hline
\end{tabular}

(-) no growth inhibition, (+)growth inhibition.

Trolox $/ \mathrm{mg}$ ) was detected in samples digested with $150 \mathrm{U} / \mathrm{mg}$ of the enzyme. For all enzymes concentrations the activity was about three times in higher after $24 \mathrm{~h}$ of digestion than at time zero.

The highest $\mathrm{Fe}^{2+}$ chelating activity (782.93 and $814.97 \mu \mathrm{g} \mathrm{Fe}{ }^{2+} / \mathrm{mg}$ ) was determined in hydrolysates obtained with 150 and $300 \mathrm{U} / \mathrm{mg}$ of enzyme after $24 \mathrm{~h}$ of reaction. In samples where the lower doses of serine proteinase was used the activity, after the same time, was reduced about two times.

The analysis of the $\mathrm{Fe}^{3+}$ reduction activity by hydrolysates produced with the Asian pumpkin proteinase showed that the activity was not increasing significantly with the reaction time. After $24 \mathrm{~h}$ of hydrolysis the determined values were in the range from 28.04 to $96.15 \mu \mathrm{g} \mathrm{Fe}^{3+} / \mathrm{mg}$, approximately three times higher in comparison to the activity detected at the beginning of the process, where this activity was mainly assigned to the activity of phosphoserine residues of $\alpha \mathrm{S} 1$ and $\beta$-casein fractions (Cervato et al., 1999; Hekmat \& McMahan, 1998).

The highest antioxidant activities were determined in all tests for the casein hydrolysate obtained with $300 \mathrm{U} /$ $\mathrm{mg}$ of the serine proteinase after $24 \mathrm{~h}$ of reaction. In comparison to the preparation digested with the enzyme dose of $150 \mathrm{U} / \mathrm{mg}$ the DPPH scavenging activity was about five times higher and the $\mathrm{Fe}^{3+}$ reduction activity three times higher, while the $\mathrm{Fe}^{2+}$ cheating activities in those two samples were similar.

The presented results are in agreement with the findings of other authors, who showed release of peptide fractions with antioxidant activities during the enzymatic degradation of casein (Suetsuena et al., 2000). During casein hydrolysis with pepsin they obtained the hexapeptide YFYPEL with a high antioxidant activity against hydroxyl radicals and DPPH. Similar activities were detected in sodium caseinate hydrolysates digested with chymotrypsin (Pralea et al., 2001). The use of microbial and plant proteinases for casein hydrolysis resulted in fractions of high antioxidant activity in the FRAP test at the level of 17 to $32 \mu \mathrm{g} / \mathrm{mg}$ of $\mathrm{Fe}^{3+}$ (Phelan et al., 2009).

The antimicrobial activity was demonstrated as the ability to inhibit the growth of $B$. cereus and P. fluorescens by obtained fractions. Among analyzed samples only three preparations had this activity. This can be explained by low level of protein degradation in the remaining samples and therefore low concentration of antimicrobial peptide.

The antimicrobial activity of milk is associated mainly with the content of immunoglobulins, lactoferrin, lysozyme, lactoperoxidase and peptides produced as a result of milk protein hydrolysis. As shown by Haque and Chand (2008), casein may be an important source of peptides with antimicrobial properties. These peptides, derived from $\alpha_{\mathrm{s} 1}$-casein, called caseicidins, were first identified in 1971 (Lahov et al., 1971). They were obtained during casein hydrolysis by chymosin at neutral $\mathrm{pH}$. Isolated caseicidins showed activity against Staphylococcus spp., Sarcina spp., Bacillus subtilis, Lactobacillus spp., Diplococcus pneumoniae and Streptococcus pyogenes. Another fragment of $\alpha_{\mathrm{s} 1}$-casein (f1-23), known as isracidin, demonstrated in vivo an antibiotic-like activity against: $S$. aureus, Candida albicans, Streptococcus pyogenes and Listeria monocytogenes, while in vitro it inhibited the growth of bacteria from the Lactobacillus group and other Gram-positive bacteria. Isracidin given to dairy cattle with diagnosed mastitis exhibited antibiotic-like effects (Haque \& Chand, 2008].

Also $\alpha_{\mathrm{s} 2}$-casein may be a source of peptides with antimicrobial properties. The first described peptide was caseicidin-I, the f150-188 positively charged fragment of native protein, isolated from fermented milk. This peptide showed inhibitory effect on the growth of Gramnegative bacteria, e.g. E. coli, and Gram-positive ones, e.g., Staphylococcus carnosus (Pihlanto \& Korhonen, 2003; Haque \& Chand, 2008). Antimicrobial properties are also observed for other peptides isolated from alpha ${ }^{-}$ casein hydrolysate, i.e. fragment f183-207 and f164-179, although the latter has a higher activity. Peptides of type were also identified in a chymosin hydrolysate of sodium caseinate. These are fragments from the C-terminus of $\alpha_{\mathrm{s} 2}$-casein: f181-207, f175-207 and f164-207. These peptides are active against many species of Gram-positive and Gram-negative bacteria. A pepsin hydrolysate of $\alpha_{\mathrm{s} 2}$-casein was shown to contain four other antimicrobial peptides: fragments f165-170, f165-181, f184-208 and f203-208 (Haque \& Chand, 2008).

An example of an antimicrobial peptide derived from $x$-casein is capacin. It is a carbohydrate-free form of caseinomacropeptide (CMP) which inhibits the growth of Gram-positive bacteria, e.g., Streptococcus mutans, and Gram-negative bacteria, e.g., Porphyromonas gingivalis. Another peptide with antimicrobial activity is the pentapeptide f17-21 isolated from the trypsin hydrolysate of $x$-casein, known as $x$-cathelicidin, a fragment of the protein. This peptide inhibits the growth of pathogens such as $S$. aureus, E. coli and S. typhimurium. There were also reports of its cytotoxic activity against certain cancer cells, such as a human leukemic cell line. Six other antimicrobial peptides are produced during the digestion of $x$-casein, and the most active fragments are: f18-24, f139-146 and f30-32, showing activity against Listeria innocua, Staphylococcus carnosus and E. coli (Haque \& Chand, 2008).

A key factor in obtaining biologically active peptides is the use of a proper proteinase of defined specificity for a selected protein substrate. Commonly used enzymes are: pepsin, trypsin and chymotrypsin, papain, ficin, bromelain or commercially available enzyme preparations of bacterial or fungal origin. A group of enzymes that can 
also be used to degrade milk proteins are non-commercial proteinases, including enzyme that we obtained from Asian pumpkin. The enzyme is characterized by an extremely high caseinolytic activity, which was demonstrated by substantial degradation of that protein immediately after the introduction of the enzyme to the reaction mixture. It belongs to a group of serine proteinases and is active in a wide $\mathrm{pH}$ range (6 to 11.5). The technologies based on the use of this enzyme can potentially have a significant commercial application owing low production costs.

\section{Acknowledgements}

This work was financially supported by the National Science Center, project no. 2011/01/B/NZ9/04297.

\section{REFERENCES}

Ardo Y, Gripon JC (1995) Comperative study of peptidolysis in some semi-chard round eyed cheese varieties with different fat contents. J Dairy Res 62: 543-547.

Benzie IFF, Strain JJ (1996) Ferric reducing ability of plasma (FRAP) as a measure of antioxidant power: The FRAP assay. Anal Biochem 239: 70-76.

Bruno MA, Lazza CM, Errasti ME, Lopez LMI, Caffini NO, Pardo MF (2010) Milk clotting and proteolytic activity of an enzyme preperation from bromelia hieronimi fruits. Food Sci Tech 43: 695-701.

Cervato G, Cazzola R, Cestaro B, (1999) Studies on the antioxidant activity of milk caseins. Int J Food Sci Nutr 50: 291-296.

Christensen TMIE, Kristiansen KR, Madsen JS (1989) Proteolysis in cheese investigated by high-performance liquid chromatography. J Dairy Res 56: 823-828.

Czajgucka A, Szołtysik M, Juszczyk P, Żelazko M, Połomska X, Dąbrowska A, Wojtatowicz M, Chrzanowska J (2007) Yeast strains isolated from Rokpol cheese - their growth in milk and hydrolytic activity against milk components. Acta Sci Pol, Biotechnologia 6: 3-13 (in Polish).

Dryjański M, Otlewski J, Polanowski A, Wilusz T (1990) Serine proteinase from Cucurbita ficifolia seed; purification, properties, substrate specificity and action on native squash trypsin inhibitor (CMTI I). Biol Chem Hoppe-Seyler 371: 889-895.

Flaczyk E, Kobus J, Rudzińska M, Buszka K, Górecka D, Szczepaniak B, Korczak J (2005) Evaluation of quality of "extra virgin" olive oils available in retail. Rośliny Oleiste — Oilseed Crops 26: 621-630.

Haque E, Chand R (2008) Antihypertensive and antimicrobial bioactive peptides from milk proteins. Eur Food Res Technol 227: 7-15.

Hekmat S , McMahon DJ (1998) Distribution of iron between caseins and whey proteins in acidified milk. Food Sci Technol 31: 632-638.

Iwaniak A, Minkiewicz P (2007) Proteins as the source of physiologically and functionally active peptides. Acta Sci Pol, Technol Aliment 6: 5-15.
Korhonen H, Pihlanto-Leppälä A (2001) Milk protein-derived bioactive peptides -novel opportunities for health promotion. IDF Bull 363: $17-26$.

Korhonen H, Pihlanto-Leppälä A, Rantamäki P, Tupasela T (1998) Impact of processing on bioactive proteins and peptides. Trends Food Sci Technol 9: 307-319.

Korhonen H, Pihlanto A (2006) Bioactive peptides: production and functionality. Int Dairy J 16: 1-15.

Kuchroo CV, Ramilly IP, Fox PF (1983) Assesment of proteolysis in cheese by reaction with trinitrobenzosulfonic acid. J Food Technol 7: 129-133.

Lahov E, Edelsten D, Sode-Morgensen MT, Sofer E (1971) Properties of basic glycopeptides released from cow milk protein by heat. Milchwissenschaft 26: 489-495.

Lowry OH, Rosebrough J, Farr AL, Randall RJ (1951) Protein Measurement with the Folin Phenol Reagent. J Biol Chem 193: 265-275.

Meisel H (2004) Multifunctional peptides encrypted in milk proteins. BioFactors 21: 55-61.

Netto FM, Galeazzi AM (1998) Production and characterization of enzymatic hydrolysate from soy protein isolate. Lebensm Wiss Technol 31: $624-631$.

Parka PJ, Jung WK, Nam KS, Shahidi F, Kim SK (2001) Purification and characterization of antioxidative peptides from protein hydrolysate of lecithin-free egg yolk. J Amer Oil Chem Soc 78: 651-656.

Pasupuleti M, Davoudi M, Malmsten M, Schmidtchen A (2009) Antimicrobial activity of a C-terminal peptide from human extracellular superoxide dismutase. BMC Research Notes 136: 1186-1192.

Pellegrini A, Thomas U, Bramaz N, Hunziker P, Fellenberg R (1999) Isolation and identification of three bactericidal domains in the bovine $\alpha$-lactalbumin molecule. Biochim Biophys Acta 1426: 439-448.

Phelan M, Aherne-Bruce SA, O’Sullivan D, FitzGerald RJ, O’Brien NM (2009) Potential bioactive effects of casein hydrolysates on human cultured cells. Int Dairy J 19: 279-285.

Pihlanto A (2006) Antioxidative peptides derived from milk proteins. Int Dairy J 16: 1306-1314.

Pihlanto A, Korhonen H (2003) Bioactive peptides and proteins. Adv Food Nutri Res 47: 175-276.

Pralea D, Dumitrascu L, Borda D, Stanciuc N (2011) Functional properties of sodium caseinate hydrolases as affected by the extent of chymotrypsinolysis. J Agro Proc Tech 17: 308-314.

Rival SG, Boeriu CG, Wichers HJ (2001) Caseins and casein hydrolysates. 2. Antioxidative properties and relevance to lipoxygenase inhibition. I Agric Food Chem 49: 295-302.

Schagger H, von Jagow G (1987) Tricine-sodium dodecyl sulfate-polyacrylamide gel electrophoresis for the separation of proteins in the range from 1 to $100 \mathrm{kDa}$. Anal Biochem 166: 368-379.

Spellman D, McEvoy E, O'Cuinn G, FitzGerald RJ (2003) Proteinase and exopeptidase hydrolysis of whey protein: comparison of the TNBS, OPA and $\mathrm{pH}$ stat methods for quantification of degree of hydrolysis. Int Dairy J 13: 447-453.

Suetsuna K, Ukeda H, Ochi H (2000) Isolation and characterization of free radical scavenging activities peptides derived from casein. I Nutr Biochem 11: 128-131.

Yen GC, Chen HY (1995) Antioxidant activity of various tea extracts in relation to their antimutagenicity. J Agric Food Chem 43: 27-32.

Xu X, Katayama S, Mine Y (2007) Antioxidant activity of triptic digest of hen egg yolk phosvitin. J Sci Food Agic 87: 2604-260. 